See discussions, stats, and author profiles for this publication at: https://www.researchgate.net/publication/260789952

\title{
Destination Management Systems: Creation of value for visitors of tourism destinations
}

Article in International Journal of Technology Management - January 2014

DOI: 10.1504/ITTM.2014.059233

CITATIONS

3

3 authors:

João Estêvão

Universidade Lusófona de Humanidades e Tecnologias

10 PUBLICATIONS 10 CitATIONS

SEE PROFILE

6 Leonor Teixeira

3 University of Aveiro

133 PUBLICATIONS 286 CITATIONS

SEE PROFILE
READS

1,382

Some of the authors of this publication are also working on these related projects:

TWINE - Co-creating sustainable Tourism \& WINe Experiences in rural areas View project

Rural Matters - Meanings of the Rural in Portugal: between social representations, consumptions and development strategies View project 


\title{
Destination management systems: creation of value for visitors of tourism destinations
}

\author{
João Vaz Estêvão* \\ ESTH/UDI, Polytechnic Institute of Guarda, \\ Rua Dr. José António Fernandes Camelo - Arrifana, \\ 6270-372 Seia, Portugal \\ Fax: +351-238-320-890 \\ E-mail: vaz_estevao@hotmail.com \\ *Corresponding author
}

\section{Maria João Carneiro}

\author{
DEGEI/GOVCOPP, \\ University of Aveiro, \\ Campus Universitário de Santiago, \\ 3810-193 Aveiro, Portugal \\ E-mail: mjcarneiro@ua.pt

\section{Leonor Teixeira} \\ DEGEI/IEETA, \\ University of Aveiro, \\ Campus Universitário de Santiago, \\ 3810-193 Aveiro, Portugal \\ E-mail: 1teixeira@ua.pt
}

\begin{abstract}
Considering the important role of information and communication technologies (ICTs) in tourism, a growing number of destination management organisations (DMOs) have been adopting more complex destination web-applications/websites to tourism destinations - destination management systems (DMSs). However, the concept of DMS is far from being consensual. The present study aims to clarify the concept of DMS by identifying the main differences between DMS and other DMO web-applications/websites regarding functionalities targeted at potential visitors of destinations. This study is carried out based on a comparison between DMS-specific and DMS-non-specific sources (papers and book chapters). The results suggest that the major difference between DMS and more traditional DMO websites relies in the transaction dimension. While DMS-non-specific reviewed sources tend to focus more on informational functionalities, DMS-specific studies clearly highlight transaction tools. The study highlights the need to develop DMS including a more varied range of transactional and communication/relationship functionalities.
\end{abstract}

Keywords: destination management organisations; DMOs; tourism destination websites; destination management systems; DMSs; functional requirements; functionalities; visitors; information and communication technologies; ICTs. 
Reference to this paper should be made as follows: Estêvão, J.V., Carneiro, M.J. and Teixeira, L. (2014) 'Destination management systems: creation of value for visitors of tourism destinations', Int. J. Technology Management, Vol. 64, No. 1, pp.64-88.

Biographical notes: João Vaz Estêvão is a researcher in the area of tourism studies. He completed his BA in Tour Operating Management at the Estoril Higher Institute for Hotel and Tourism Studies, in Portugal. In 2004, he completed his MSc in Local Tourism Destination's Management at the University of Barcelona, Spain. He is currently undertaking a $\mathrm{PhD}$ in Tourism at the University of Aveiro, Portugal. His $\mathrm{PhD}$ research subject is the adoption of Information Technologies by tourism destinations. Regarding his current professional activity, he is a Professor at the School of Tourism and Hospitality Management of the Polytechnic Institute of Guarda, in Portugal, where he lectures subjects in the areas of tour operations, tourism planning and development and information technologies in tourism. He is also a member of the Research Unit for Inland Development (UDI). He has presented papers in more than ten national and international conferences and workshops.

Maria João Carneiro is Assistant Professor of Tourism at the University of Aveiro (UA) (in Portugal) and Researcher at the Governance, Competitiveness and Public Policy (GOVCOPP) research unit at this University. She holds a Degree in Tourism Management and Planning from UA, an MBA from New University of Lisbon and a PhD in Tourism from UA. She is the Director of the degree program (licenciatura) in Tourism of the UA. She has published papers in several journals and conference proceedings, and has also presented several works in conferences and seminars. Her research interests are competitiveness of tourism destinations, consumer behaviour in tourism and destination marketing.

Leonor Teixeira is an Assistant Professor of Technology and Information Systems area in the Department of Economics, Management and Industrial Engineering at the University of Aveiro (Portugal). She graduated in Management and Industrial Engineering in 1997, received her MSc in Information Management in 2002, and $\mathrm{PhD}$ in Software Engineering applied in Health Information Systems in 2008. She has published in several journals as Computer Methods and Programs in Biomedicine, Journal of Information Science and Engineering, International Journal of Engineering Science and Technology, Haemophilia Journal, Journal of Information Technology and Tourism, EducaOnline Journal, and currently she is a Researcher at the Institute of Electronics and Telematics Engineering (IEETA). Her current research interests include software engineering, information management and software development in different domains.

\section{Introduction}

The emergence of the internet has completely transformed the global economy, namely the relations among suppliers and between them and their customers, optimising management, business-to-business (B2B) cooperation and production practices (Castells, 2001). Nowadays, information and communication technologies (ICTs) continue to have a profound effect on the economies and societies where they are used (Ho et al., 2007). 
Regarding the evolution of the internet in terms of its users, the worldwide growth has been exponential. Hence, according to the Internet World Stats (2013), while in the year 2000 there were 360,985,492 internet users worldwide, in June 2012 their number increased to $2,405,518,376$, representing a growth of $566 \%$ in only 12 years. However, the internet penetration rate is very different between nations and continents. Thus, while in June 2012, the internet penetration reached $78.6 \%$ of the population in North America, the highest in the world, Africa only reached $15.6 \%$ in the same period, being the world average penetration rate around 34.4\% (Internet World Stats, 2013). In the USA alone, the online market in terms of the value of commercial transactions rose up from a market share of only $20 \%$ in 2003 to $33 \%$ in 2009 , representing a total of 91 billion dollars in eCommerce transactions (JupiterResearch, 2011).

Electronic markets substantially benefit from ICTs such as the internet, since product information can be disseminated with a higher speed, quantity and quality (Öörni, 2004). Due to the nature of the tourism sector, which is highly intangible and also demands suppliers to promote their products to potential customers at a global scale, tourism was, undoubtedly, one of those sectors which were more dramatically transformed by the advent of the internet (World Tourism Organization Business Council, 1999). In fact, according to Werthner and Klein (1999), tourism is perceived as a leading sector and even as a driver of business-to-consumer (B2C) eCommerce.

The advent of the internet opened a whole new range of possibilities but also created challenges to individual tourism suppliers and to destinations as a whole. According to Buhalis (2003) the internet brought some key innovations, such as 'melting' down geographical barriers in both B2B and B2C perspectives, which enhanced the capacity of tourism suppliers to act at a global level with much less financial costs, and also allowed visitors of tourism destinations to become more informed, and autonomous.

The so called destination management organisations (DMOs) soon became aware of the potential relevance of the internet in optimising destination marketing efforts. They recognised the potential of the internet to increase the opportunities of contact with consumers and to do that at a substantially lower cost. According to Gartrell (1988), DMOs, often public or public-private entities (Pollock, 1995), should be the main actor fostering coordination amongst the variety of actors (public and private) of the destination. They should provide leadership within the local, regional or national tourism system, promote the development of a sustainable tourism activity, provide some facilities and services to visitors, such as tourism information offices or signage, which complement the hospitality sector's offerings and enhance visitors' satisfaction levels towards the destination (Hall, 2000). Thus, in order to better fulfil their tasks, DMOs started to develop destination websites.

Nevertheless, traditional DMO websites are often limited to the task of promoting destinations as a whole without actively empowering a closer and more personalised relationship with potential visitors (World Tourism Organization, 2004). These websites are typically limited to a mere informational dimension. However, in recent years, a small number of destinations have been able to implement and successfully develop advanced and more dynamic destination web platforms, the so called destination management systems (DMSs) (e.g., Pollock, 1995; Sussmann and Baker, 1996; Buhalis, 2003; Collins and Buhalis, 2003). These platforms are networks linking the DMO to the whole range of destination suppliers (e.g., hotels, restaurants) and, at the same time, actively engage with the potential tourist demand. While traditional DMO websites are likely to be mere electronic brochures of destinations, only encompassing information to visitors, DMS 
provide a network linking tourism actors, thus assisting DMOs to manage and coordinate the tourism development process in itself. Taking into consideration several definitions of DMS proposed (e.g., Pollock, 1995; Rita, 2000; Buhalis, 2003; Ndou and Petti, 2007), these platforms seem to encompass not only informational functionalities, but also a whole set of functionalities, including, for example, those that enable the purchase of goods and services through the website.

However, the concept of DMS is far from being consensual and, therefore, it is not easy to identify the functionalities that distinguish DMS from other kinds of DMO websites. Although there is considerable literature on DMS, most of it focuses on their advantages to destinations (e.g., Brown, 2004; Kärcher and Alford, 2008; O'Connor and Rafferty, 1997) or on the pre-requisites or barriers to their implementation (e.g., Buhalis and Spada, 2000; Sussmann and Baker, 1996; Alford and Clarke, 2009), often taking the form of case studies.

The present study intends to contribute to improve the value of DMS, by fulfilling the research gap previously identified, specifically, to clarify the concept of DMS and help defining the frontiers of this kind of web-application. It is also aimed to identify the main differences between DMSs and other DMO websites regarding the functionalities targeted at potential visitors. This study will be carried out based on the analysis of literature on the destinations' web-applications/websites.

\section{Theoretical foundations}

The present study intends to contribute to fulfil the research gap previously identified in order to clarify the concept of DMS and help defining the frontiers of this kind of web-application. However, a theoretical discussion of the use of internet by DMOs, of the existing DMS concept and of DMS architecture, seems essential to grasp the relevance and implications of the subsequently described analysis.

\subsection{Destination management organisations' use of the internet}

Destinations are places with some form of actual or perceived borders, such as physical or market-created boundaries (Kotler et al., 2003). According to Buhalis (2003), destinations are amalgams of tourism products that should be offered to visitors in a cohesive and integrated fashion. Every destination is a bundle of components with different functions aimed at responding to visitors' needs.

The main components of destinations proposed by Cooper et al. (2008) are

1 'attractions', both natural or man-made, that usually correspond to the pull factors generating tourism demand (e.g., beaches, monuments)

2 'amenities', which include all profitable or non-profitable tourism services and facilities that allow and/or facilitate tourism experiences (e.g., accommodation)

3 'access', that encompass transportation means, routes and terminal serving the destination

4 'ancillary services', often non-profitable tourism services on-site (e.g., tourism information offices and signage) usually delivered by DMOs. 
Middleton and Clarke (2002) suggest that tourism destinations present the following components:

1 'attractions and environment' (e.g., landscape, monuments)

2 'destination facilities and services' (e.g., accommodation, restaurants)

3 'accessibility of the destination'

4 'images of the destination'

5 'price to the consumer' (sum of the costs of visiting the destination).

Most DMOs are not producers of tourism services. In general, they do not engage in selling any goods and services of the destination to visitors and are not responsible for the quality of specific isolated tourism services. According to Crouch (2007), while private individual tourism suppliers strive to promote their own offering, the DMOs are often seen as the entity that markets a destination as a whole. Although the DMS often foster or develop planning and development processes aiming at enhancing the destinations' quality and balance, one of the DMOs main functions is to promote destinations. As Middleton and Clarke (2002) argue, they have a major role in marketing the tourism products of a country or a region in a coherent way. However, despite the fact that a considerable part of local, regional and national DMOs spend the largest portion of their budgets in costly promotional initiatives, often using mass media (e.g., television, radio or press advertisements), only a few of them develop marketing efforts by means of a systematic approach (Crouch, 2007). Thus, as suggested by Kotler et al. (2003), the desire to develop a recognised destination-brand presents a difficult marketing challenge to DMOs.

The technological revolution empowered by the advent of the internet has had a dramatic impact in the operation, structure and strategy of tourism-related organisations (Buhalis, 2003). Both the ways of acquiring tourism products (Buhalis, 2003) and the ways by which tourists search for information (Wöber, 2003) and comment on their travel experiences (Yoo and Gretzel, 2010), have been gradually but consistently altered. The internet has radically transformed the way and intensity in which tourists and tourism destinations interact. It has become the main vehicle used by DMOs to communicate with past, present and potential future visitors.

Choi et al. (2007a) argue that official destinations websites provide information for tourists while promoting and marketing the destination's image (at local, regional or national levels). Many DMOs strongly strive to place and promote their online communication, combining diverse kinds of functionalities to assist visitors in their search stage, providing information on flights, accommodations, maps and directions, weather attractions (Crouch, 2007). After the decision has been taken, visitors tend to acquire more specific information on concrete suppliers and purchase tourism services in other types of web platforms, such as travel search engines (TSE) or the suppliers' own websites (Choi et al., 2007b).

DMOs usually operate on the internet through their own promotional websites, often static brochure-like platforms (World Tourism Organization, 2004). More recently, mainly due to the advent of Web 2.0 (O'Reilly, 2005), the online presence of DMOs has dispersed itself and spread to social network websites (Mich and Kiyavitskaya, 2011). However, only a scarce number of destinations have been able to successfully implement an official web presence reaching beyond the information dimension 
(World Tourism Organization, 2004) and providing a one stop-only service also allowing tourists to book/purchase services dynamically (e.g., dynamic packaging) while directly communicating with the destination (Buhalis, 2003). The systems that offer these opportunities are usually referred to as DMSs.

\subsection{Destination management systems}

Given the fact that the present study will focus on DMS-specific functionalities, it seemed pertinent to include a conceptual approach which will include the main advantages and architecture scenarios inherent to this kind of systems.

\subsubsection{The blurred concept of DMS}

Although there is still not a universally adopted concept of DMS (Egger and Buhalis, 2008), there is large consensus in considering these systems, when successfully implemented, more advanced and beneficial than traditional official destination web platforms which are often limited to the basic task of promoting destinations. In fact, DMS go much beyond the promotional sphere. Under a B2B perspective, they assist destinations to jointly and coherently promote and sell their offerings to prospective visitors while allowing more systematic communication flows between suppliers aiming at fostering collaboration efforts within the destination (Dwyer et al., 2009; Pollock, 1995). Under a B2C/C2B perspective, DMS allow visitors to search, plan and dynamically purchase tourism products without leaving the official destination information system (IS) (Egger and Buhalis, 2008). Although arguing that DMS are systems underpinning the primary objective of a DMO - promotion - Rita (2000, p.2) recognises that they normally include booking and purchase tools, encompassing a "desire to use computer and communication technologies to provide what has been called visibility and accessibility - an information and reservations approach".

\subsubsection{The main advantages of DMS}

Among the most frequently mentioned advantages of DMS for both destinations' suppliers and visitors (Brown, 2004; Buhalis, 2003; Buhalis and Spada, 2000; Egger and Buhalis, 2008; Petti and Solazzo, 2007; Pollock, 1995; Rita, 2000; World Tourism Organization, 2001) regarding destination development, one can outline enhanced visibility of small and medium-sized tourism enterprises (SMTEs) diminishing their dependency on external intermediaries and, consequently, allowing them to reach higher revenues (Buhalis, 2003; Cooper, 2006; Ndou and Petti, 2007). Dwyer et al. (2009) suggest that the internet allowed smaller firms, often family-ran, to engage in marketing activities in direct contact with prospective visitors, enabling them to compete for market share with larger firms.

Another major advantage of DMS is the fact that they foster coordinated promotion and distribution of the whole destination leading to a higher cohesion among various stakeholders that share the same marketing and eCommerce platform. In fact, when analysing the utility of information elements available in destination portals, Teichmann and Zins (2008, p.209) consider that "the more features the website incorporates the more it can meet the needs of consumers at different information consumption stages". DMS not only provide information about various elements of the destination as they also allow 
reservations (Buhalis, 2003). They also give members (usually destination-based companies) access to privileged information and tools usually available for DMS affiliate members (image bank, destination's facts and figures, legal documentation).

At a macro-economic level, DMS can assist entire countries diversifying their supply and its territorial distribution, and also communicating with a more autonomous and mature demand that does not usually search for pre-assembled package tours from traditional intermediaries. DMSs also contribute to a higher cohesion inside the destination and, consequently, to a more coordinated promotion of the destination. DMSs usually act as hubs connecting internal resources of the destinations with external ones (Inversini and Cantoni, 2009), emphasising the marketing role of the destination toward the visitors. They are often defined as complex systems which facilitate the management of a wide range of requests from different users and stakeholders of a DMO (Buhalis, 2003). DMS enhance DMOs ability to assist the visitors' experience before, during and after the visit (Gretzel et al., 2006) as well as to coordinate all the partners and industries involved in the production and delivery of tourism goods.

\subsubsection{DMS architecture}

Although DMS are considered the most advanced web platforms available to DMOs, evidence clearly shows that, since their inception in the mid-'90s, only a few destinations were able to successfully develop and implement such systems (Alford and Clarke, 2009; Buhalis and Spada, 2000). This poor record in terms of DMS implementation success is mostly due to tourism destination configurations (Ndou and Petti, 2007) and stakeholders attitudes rather than to mere technological issues (Sussmann and Baker, 1996). Additionally, not all DMS have the same system architecture, as the levels of eReadiness or the stages of development of DMOs' eTourism strategies also tend to differ from a destination to another.

Petti and Solazzo (2007) identified several types of DMS technological architectures suitable to different stages of destination configuration and coordination proposed by Ndou and Petti (2007): autonomous; cooperation; leadership; and distributed leadership. The DMS configurations proposed by Petti and Solazzo (2007) focus on the transactional capabilities of DMS. Petti and Solazzo (2007) argue that in the first destination configuration, characterised by poor tourism planning, no decisional centres, fragmented supply and low levels of ISs use (Ndou and Petti, 2007), DMS are unlikely to emerge and DMO is the only possible actor managing the destination, informing suppliers by a fax or GSM message when tourists asks for a service. Within the cooperation stage, where the supply is relatively structured, there is a limited number of ad hoc decisional centres and most suppliers have legacy ISs (Ndou and Petti, 2007), DMO is still the only stakeholder managing the DMSs and DMSs are able to register service requests, availability and process transactions directly on the suppliers' IS (Petti and Solazzo, 2007). In the third stage (Ndou and Petti, 2007) - leadership - the supply is structured, the DMO is the single decisional centre that coordinates the supply and DMSs play a major role in the coordination, promotion and distribution of the destination (Petti and Solazzo, 2007). The fourth and last destination configuration proposed by Ndou and Petti (2007) - distributed leadership - is characterised by a strong maturity of the tourism destination suppliers in terms of the accumulation of high managerial and technological humanware. At this stage suppliers have a reduced need for a DMO, tending to self-organise (Ndou and Petti, 
2007). According to Petti and Solazzo (2007), in the distributed leadership stage, each of the suppliers' IS publishes their own offerings on a universal description, discovery and integration (UDDI) registry, while DMSs allow suppliers to have their own services and to publish them as web services on a UDDI registry. In case the supplier has its software application on its own IS, it must develop a proxy component following technological standards for web service or for application programming interface (API). In this scenario, the DMS can look up the UDDI registry and build an ad-hoc proxy component in order to use the tourism businesses.

Brown (2004) also addresses two types of DMS concerning 'bookability'. The author argues that some DMS have 'real time booking' capabilities, with suppliers committing to provide updated availability and pricing at all times allowing the DMS to produce instant booking information. 'Pseudo-real time booking' DMSs also require suppliers to provide availability and pricing information but ask users to make a book enquiry that will be later confirmed or rather refused by the supplier.

Indeed, the DMSs' need to operate an integration of systems of different stakeholders requires different access levels, according to the type of stakeholder, using graphical user interfaces (GUI) or API/web services (Figure 1). Thus, DMSs are not only expected to hold an internet website open to everyone - namely prospective visitors - but also to create different user profiles aimed at both destinations' suppliers/intermediaries and the DMO itself. In a DMS context, the system is expected to support a user profile only accessible to the DMO's staff aiming to assist its own internal functions (e.g., allowing the staff of different DMO tourism information offices to access the central database, thus providing up to date and homogeneous information). A DMS is also required to offer selected destination suppliers admission to yet another user profile in which, for example, strategic data produced by the DMO (such as statistics) can be accessed.

Figure 1 The main actors of a DMS (see online version for colours)

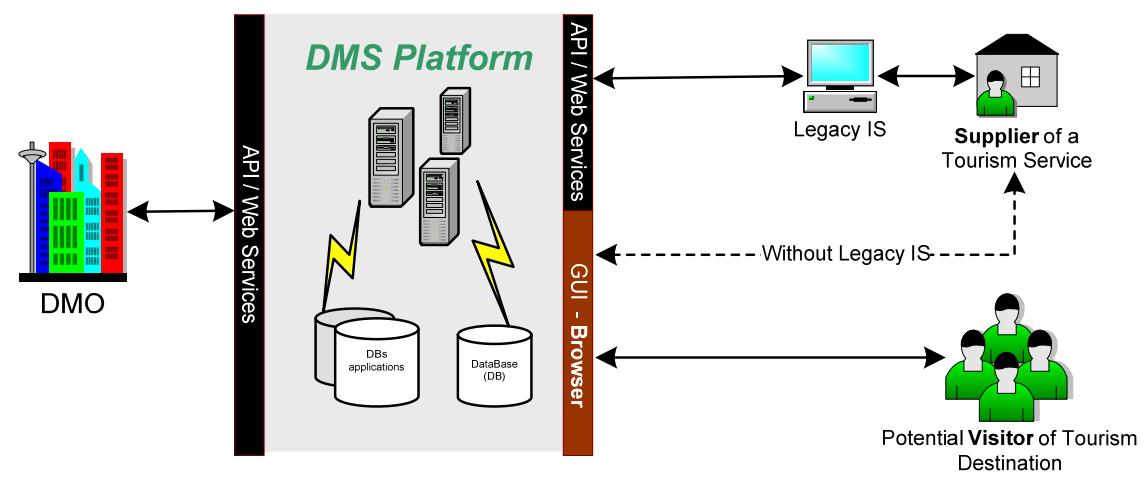

DMSs differ from more traditional DMO websites/web-applications, since these later ones only have a user interface for prospective tourists and do not convey user profiles for DMOs staff or for destination-based actors. Thus, any comparison beyond functionalities not targeted to visitors (open user profile) would not be possible because most common destination websites do not simply hold them. By analysing the literature (e.g., Buhalis, 2003; Han and Mills, 2006; Wang and Fesenmaier, 2006) the major difficulty in distinguishing DMS from other DMO web-applications/websites resides in 
visitor profiles, specifically on functionalities directed at visitors of tourism destinations, where differences between both types of systems may be harder to detect. According to authors such as Booch et al. (1999), the elements needed to interact with systems can be designated as functional requirements. Both the literature on ISs as well as on IT in tourism use different nomenclatures to designate these elements, such as 'functions', 'tools' and 'functionalities'. In the present study, these elements will be referred to as functionalities.

Previous research on tourism website functionalities - namely those evaluating website effectiveness - often categorise functionalities targeted at potential visitors of tourism destinations according to a set of pre-determined criteria that best fit each research goals. For instance, for website evaluations, a popular instrument among researchers is the modified balance scorecard (MSC) developed by Mills and Morrison (Douglas and Mills, 2004), which groups functionalities according to technical aspects, user friendliness, attractiveness and marketing effectiveness. In eMICA - another model adopted by Doolin et al.'s (2002) for evaluating DMO websites - functionalities are classified in three groups - 'promotion', 'provision of information' and 'transaction processing' - each representing an additional layer of complexity (Doolin et al., 2002). Beldona and Cai (2006) identified three perceived levels of DMO websites' stickiness grouping functionalities into three categories: content, interactivity and promotional value. Another completely different perspective is suggested by Bastida and Huan (2012), which evaluated the city DMO websites, classifying functionalities in three groups according to the phases of travel preparation: 'information/tools visitors need before the trip', 'information/tools visitors need during the trip' and 'the website itself' (this last group encompassed functionalities not related to a specific stage of a travel preparation stage).

Other stream of research aims to assess the relevance of functionalities for different types of actors. Indeed, in order to assess the importance given by DMO CEOs to different DMS functionalities, Wang (2008) proposed a conceptual model classifying them into four dimensions according to their role: 'information'; 'communication'; 'transaction'; and 'relationship'. Similarly to Doolin et al.'s extended eMICA model, the Wang's dimensions not only represent different sets of tasks performed by the website, but also additional levels of functionalities' sophistication, complexity and interactivity (Wang and Russo, 2007). The first dimension - information - refers to the types and levels of information that need to be accessible in a DMS in order to attract visitors (e.g., visualisation of accommodation options, schedules and general descriptions of destinations' features). Communication functionalities (e.g., search functions, frequently asked questions) are of paramount importance because any successful DMS must provide tourists with appropriate communication mechanisms to enhance the understanding between consumers and suppliers. Transaction functionalities encompass, for example, reservation and purchase tools. They promote engagement between the destination and the consumer, previously strengthened by the trust built from a quality exchange of information and timely communication (Wang and Russo, 2007). Transaction functionalities are often challenging for DMO since they require high levels of involvement from local suppliers, up to date availability, pricing and booking confirmation from suppliers (Brown, 2004). The relationship dimension encompasses functionalities empowering long-lasting and positive relationships with potential and past visitors such as personalisation, customer loyalty programmes. 


\section{Methodology of the study}

The main objective of this study is to help clarifying the concept of DMS. Given that, as previously referred, the major difficulty in distinguishing DMSs from other DMO web-applications/websites relies on the set of functionalities targeted at potential visitors of destinations, the analysis of the current study focused on this kind of functionalities. In order to achieve the main objective of the study, first, potential functionalities of DMS targeted at potential visitors were identified. These functionalities were identified based on an analysis of literature on DMSs and based on literature on web-applications/websites, not specific on DMSs. The literature not specific on DMSs encompassed literature regarding other web platforms which are not DMSs and, also, literature regarding DMO platforms in general, where the type of web platform was not specified. A content analysis of each source (paper or book chapter) was done, in order to identify all functionalities targeted at visitors.

All functionalities were grouped and later analysed following two main criteria. One of the criteria was the kind of requirement underlying the functionality. In this context, functionalities were grouped following a similar approach to that proposed by Wang and Russo (2007), into three dimensions: information, communication/relationship and transaction. Due to obvious similarities between the communication and relationship dimensions, as well as to the fact that only a relatively scarce number of functionalities were found in each of the two dimensions, it was considered appropriate to classify them in the same group.

The other criterion adopted to classify the functionalities was the component of the tourism destination to which the functionality was related (e.g., attractions, access). The components of tourism destinations identified by Cooper et al. (2008) - attractions, amenities, access and ancillary services - were used to group all the identified functionalities. However, due to the broad nature of both attractions and amenities, each of these two components was divided into three subcategories. Thus, while the component attractions was split into natural attractions, man-made attractions and events, the component amenities was subdivided into accommodation, intermediaries and other amenities. However, the nature of certain identified functionalities excludes the possibility of relating them to any type of tourism destination component in particular. This is the case of the web platforms' 'complementary general requirements', which include contents and functionalities such as sitemaps, FAQs, secure transactions, multi-languages, among others. This type of requirement is essential to ensure the good performance of the functional requirements of the system by ensuring the quality of the whole system. Thus, a fifth category - complementary general requirements (CGR) - was added in the second criteria.

Moreover, an analysis of the main differences between DMS and other DMO websites regarding functionalities targeted at potential visitors, was performed. In order to carry out this analysis, the DMS-specific literature and the DMS-non-specific literature was compared. Chi-square tests were used to identify statistically significant differences between DMSs and other DMO websites on the three dimensions of functionalities previously referred.

The papers were identified by searching in some of the largest and most popular online scientific databases in the field of study under analysis (e.g., Science Direct). Literature non-specific on DMS was searched using groups of keywords such as 'destination websites', 'DMO websites', 'NTO websites' and 'city websites'. The search 
for studies on DMS included keywords such as 'DMSs', 'destination marketing systems' and 'destination ISs'. Two other relevant publications in the field, not included in the most popular databases previously searched - 'Journal of Information Technology and Tourism' and the 'Proceedings of ENTER' (the International Federation for Information Technologies and Travel \& Tourism's annual conference) -, were also consulted online. Reference books in the field of technologies applied to tourism were also consulted to identify book chapters on the subject under analysis.

Only sources which included a quite holistic perspective of the components of tourism destinations and of types of functionalities were considered. Therefore, sources focusing on very specific features of the destination (e.g., gastronomy) or on very specific kind of functionalities were excluded from the study. Moreover, only studies encompassing lists or, at least, systematic enumerations of functionalities were analysed.

In this study, a total of 48 sources (papers or book chapters) published between 1996 and 2012 were analysed: 22 specific on DMSs and 26 not specific on DMSs. Both the scope and research goals of the literature sources are considerably diverse. However, most reviewed sources encompass researches evaluating destination websites, case studies describing contents of functionalities of a specific destination web platform. Thus, while some studies enumerate and describe the whole range of functionalities of the destinations' web platforms (e.g., Li and Wang, 2010), others do not have such a systematic approach, only mentioning a few functionalities to exemplify certain functions or benefits inherent to a specific destination web application. Table 1 illustrates the scope of each of the analysed papers and book chapters.

Table 1 List of reviewed studies and correspondent topics

\begin{tabular}{|c|c|c|}
\hline Author(s) & Type of study & Research topic and goals \\
\hline Baggio (2008) & DMS-non-specific & $\begin{array}{l}\text { Case study describing Rimini's DMO web based } \\
\text { platform }\end{array}$ \\
\hline $\begin{array}{l}\text { Bastida and } \\
\text { Huan (2012) }\end{array}$ & DMS-non-specific & $\begin{array}{l}\text { Performance evaluation of Chinese tourism } \\
\text { website's information }\end{array}$ \\
\hline $\begin{array}{l}\text { Benckendorff } \\
\text { and Black (2000) }\end{array}$ & DMS-non-specific & Case Study on Australian DMOs' web marketing \\
\hline $\begin{array}{l}\text { Bédard and } \\
\text { Louillet (2008) }\end{array}$ & DMS-specific & Case Study describing Québec's DMS \\
\hline $\begin{array}{l}\text { Beldona and } \\
\text { Cai (2006) }\end{array}$ & DMS-non-specific & $\begin{array}{l}\text { Evaluation study of } 50 \text { US rural tourism websites' } \\
\text { stickiness }\end{array}$ \\
\hline Brown (2004) & DMS-specific & $\begin{array}{l}\text { Case study on the official Manchester DMS } \\
\text { identifying its critical success factors }\end{array}$ \\
\hline Buhalis (2003) & DMS-specific & $\begin{array}{l}\text { Conceptualisation of destination management } \\
\text { systems }\end{array}$ \\
\hline $\begin{array}{l}\text { Buhalis and } \\
\text { Spada }(2000)\end{array}$ & DMS-specific & Identification of success criteria for DMS \\
\hline $\begin{array}{l}\text { Cano and } \\
\text { Prentice (1998) }\end{array}$ & DMS-non-specific & $\begin{array}{l}\text { Study on the marketing and communication } \\
\text { potential of Scottish DMO websites }\end{array}$ \\
\hline Çetinkaya (2009) & DMS-specific & $\begin{array}{l}\text { Descriptive study on the role of DMSs for } \\
\text { destination competitiveness }\end{array}$ \\
\hline $\begin{array}{l}\text { Chen and } \\
\text { Sheldon (1997) }\end{array}$ & DMS-specific & $\begin{array}{l}\text { Identification of challenges encountered in the } \\
\text { design of a DMS }\end{array}$ \\
\hline
\end{tabular}


Table 1 List of reviewed studies and correspondent topics (continued)

\begin{tabular}{|c|c|c|}
\hline Author(s) & Type of study & Research topic and goals \\
\hline Cho and Sung (2012) & DMS-non-specific & $\begin{array}{l}\text { Cross-cultural effects on perceived information } \\
\text { value and performance evaluation in travel } \\
\text { destination websites }\end{array}$ \\
\hline Choi et al. (2007b) & DMS-non-specific & $\begin{array}{l}\text { Identification of the image representations of } \\
\text { Macau by analysing Macau's DMO website, } \\
\text { among other web sources }\end{array}$ \\
\hline Choi et al. (2007a) & DMS-non-specific & $\begin{array}{l}\text { Study on the preferences and attitudes of } \\
\text { consumers towards DMOs functionalities }\end{array}$ \\
\hline $\begin{array}{l}\text { Collins and } \\
\text { Buhalis (2003) }\end{array}$ & DMS-specific & $\begin{array}{l}\text { Analysis of the degree of development } \\
\text { and use of DMS in England }\end{array}$ \\
\hline Doolin et al. (2002) & DMS-non-specific & $\begin{array}{l}\text { Evaluation of the level of website development in } \\
\text { New Zealand's RTOs using the extended model } \\
\text { of internet commerce adoption }\end{array}$ \\
\hline $\begin{array}{l}\text { Douglas and } \\
\text { Mills (2004) }\end{array}$ & DMS-non-specific & $\begin{array}{l}\text { Comparative analysis of ten Caribbean NTO } \\
\text { websites to determine differences in terms of } \\
\text { technical aspects, user friendliness and } \\
\text { marketing effectiveness }\end{array}$ \\
\hline Estêvão et al. (2012) & DMS-specific & $\begin{array}{l}\text { Study on the role of DMS in the purchase of } \\
\text { cultural tourism products }\end{array}$ \\
\hline Estêvão et al. (2011) & DMS-specific & $\begin{array}{l}\text { Study aiming to identify potential } \\
\text { benefits in adopting DMSs in Portugal }\end{array}$ \\
\hline Feng et al. (2003) & DMS-non-specific & $\begin{array}{l}\text { Comparative evaluation study between } \\
\text { US and Chinese destination websites }\end{array}$ \\
\hline $\begin{array}{l}\text { Giannopoulos and } \\
\text { Mavragani (2011) }\end{array}$ & DMS-non-specific & $\begin{array}{l}\text { Comparative analysis of European } \\
\text { national tourism websites }\end{array}$ \\
\hline Guthrie (2008) & DMS-specific & Case study describing the DMS VisitBritan \\
\hline Han and Mills (2006) & DMS-non-specific & $\begin{array}{l}\text { Methodology and testing techniques } \\
\text { for tourism website evaluation }\end{array}$ \\
\hline Inversini (2011) & DMS-specific & $\begin{array}{l}\text { Study on web marketing and communication of } \\
\text { cultural destinations }\end{array}$ \\
\hline Kao et al. (2005) & DMS-non-specific & $\begin{array}{l}\text { Study on the satisfaction of Taiwanese tourists } \\
\text { towards Singapore's NTO website }\end{array}$ \\
\hline $\begin{array}{l}\text { Kärcher and } \\
\text { Alford (2008) }\end{array}$ & DMS-specific & Case study describing the DMS Tiscover \\
\hline Li and Wang (2010) & DMS-non-specific & Evaluation model for DMO websites \\
\hline Loda et al. (2009) & DMS-non-specific & $\begin{array}{l}\text { Website content analysis aiming to determine the } \\
\text { most frequently used elements }\end{array}$ \\
\hline $\begin{array}{l}\text { Luna-Nevarez and } \\
\text { Hyman (2012) }\end{array}$ & DMS-non-specific & $\begin{array}{l}\text { Content analysis identifying typical features of } \\
\text { destination websites }\end{array}$ \\
\hline Milheiro (2006) & DMS-non-specific & $\begin{array}{l}\text { Evaluation study on the usability of the } \\
\text { Portuguese NTO website }\end{array}$ \\
\hline Miralbell et al. (2008) & DMS-non-specific & $\begin{array}{l}\text { Case study describing the Spanish NTO web } \\
\text { platform Spain.info }\end{array}$ \\
\hline Morrison et al. (2004) & DMS-non-specific & $\begin{array}{l}\text { Study on the approaches to tourism and } \\
\text { hospitality website evaluation }\end{array}$ \\
\hline
\end{tabular}


Table 1 List of reviewed studies and correspondent topics (continued)

\begin{tabular}{|c|c|c|}
\hline Author(s) & Type of study & Research topic and goals \\
\hline $\begin{array}{l}\text { O'Connor and } \\
\text { Rafferty (1997) }\end{array}$ & DMS-specific & Case study on the Irish DMS Gulliver \\
\hline $\begin{array}{l}\text { Pechlaner and } \\
\text { Raich (2002) }\end{array}$ & DMS-specific & $\begin{array}{l}\text { Case study on the DMS Tiscover (Tyrol) aiming } \\
\text { to analyse its role in the information process } \\
\text { within cultural tourism products }\end{array}$ \\
\hline Qi et al. (2008) & DMS-non-specific & Evaluation of Chinese DMO website's usability \\
\hline Rita (2000) & DMS-specific & $\begin{array}{l}\text { Guidelines required for DMOs to achieve } \\
\text { successful web marketing }\end{array}$ \\
\hline Schröksnadel (2008) & DMS-specific & $\begin{array}{l}\text { Case study describing the Austrian-based DMS } \\
\text { Feratel }\end{array}$ \\
\hline So and Morrison (2004) & DMS-non-specific & $\begin{array}{l}\text { Content analysis aiming to measure the } \\
\text { effectiveness of East Asian NTO websites }\end{array}$ \\
\hline $\begin{array}{l}\text { Stepchenkova et al. } \\
\text { (2010) }\end{array}$ & DMS-non-specific & $\begin{array}{l}\text { Evaluation study of } 967 \text { US DMO websites } \\
\text { assessing overall technical functionality, customer } \\
\text { friendliness/usability and marketing effectiveness }\end{array}$ \\
\hline $\begin{array}{l}\text { Sussmann and } \\
\text { Baker (1996) }\end{array}$ & DMS-specific & $\begin{array}{l}\text { Exploratory study on the record of DMS and } \\
\text { questioning the robustness of the concept }\end{array}$ \\
\hline $\begin{array}{l}\text { Teichmann and } \\
\text { Zins (2008) }\end{array}$ & DMS-non-specific & $\begin{array}{l}\text { Approach for measuring perceived utility of } \\
\text { information elements on DMO websites }\end{array}$ \\
\hline $\begin{array}{l}\text { The European } \\
\text { e-Business Market } \\
\text { Watch (2005) }\end{array}$ & DMS-specific & $\begin{array}{l}\text { European Commission report on DMSs analysing } \\
\text { two of these systems successfully in the EU: } \\
\text { Tiscover (Tyrol) and Gulliver (Ireland) }\end{array}$ \\
\hline Wang (2008) & DMS-specific & $\begin{array}{l}\text { Study aiming to assess the critical factors of } \\
\text { web-based DMSs used by US DMOs }\end{array}$ \\
\hline $\begin{array}{l}\text { Wang and } \\
\text { Fesenmaier (2006) }\end{array}$ & DMS-non-specific & Web marketing practices of US DMOs \\
\hline Wang and Russo (2007) & DMS-specific & $\begin{array}{l}\text { Study proposing a conceptual model regarding } \\
\text { DMS functions }\end{array}$ \\
\hline Wei and Jiu-Wei (2009) & DMS-specific & Study on the strategic dimension of DMS \\
\hline $\begin{array}{l}\text { World Tourism } \\
\text { Organization (2001) }\end{array}$ & DMS-specific & Guidelines for DMS implementation by DMOs \\
\hline $\begin{array}{l}\text { Zhou and } \\
\text { DeSantis (2005) }\end{array}$ & DMS-non-specific & $\begin{array}{l}\text { Website content analysis aiming to identify } \\
\text { usability challenges and evaluate cross-cultural } \\
\text { differences in international tourism websites }\end{array}$ \\
\hline
\end{tabular}

\section{Results analysis}

In this section, the main outcomes of the present research will be presented and analysed. The section is structured in three subsections. First, the diversity of functionalities identified in the literature is discussed. Secondly, the overall frequency of references to the three adopted website dimensions - 'information'; 'communication/relationship'; 'transaction' - is analysed. Lastly, a comparative analysis between the types of functionalities found in DMS-specific and DMS-non-specific reviewed studies is done. 


\subsection{The variety of website functionalities identified in the literature sources}

Regarding the variety of functionalities identified in the reviewed studies, it seems noteworthy that within the total of about 170 functionalities identified in the literature, the highest proportion (around 60\%) fits in the information dimension which corresponds to the visualisation/querying of different kinds of information. As shown in Figure 2, the most often identified information functionalities are 'information on attractions', 'information on accommodation' and 'information on recreation/activities/entertainment'. Thus, this dimension has the highest variety of functionalities, followed by the 'communication/relationship' dimension (which includes about $30 \%$ of all the functionalities). Within this dimension, the more frequently referred functionalities are 'search functions' (not associated to a specific destination component), 'travel/trip planner' and 'frequently asked questions' (Figure 3).

The lowest diversity in terms of references to functionalities is found within the transaction dimension (that encompasses around $10 \%$ of the functionalities identified). 'Online reservations/transactions' (not associated to a specific destination component), 'accommodation reservations' and 'purchase of event tickets' are the most often identified functionalities under the transaction dimension (Figure 4). The scarce variety of identified transactional functionalities may be explained by two main reasons: firstly, no transactional functions were identified within the ancillary services component because, as referred by Crouch (2007), these services are usually provided by DMOs for free. Secondly, because the transaction dimension is narrower than the other two dimensions regarding its types of functionalities. Thus, it does not inherently have a great diversity beyond the booking and purchase of tourism services.

Figure 2 Most frequently referred functionalities in reviewed studies (information dimension) (see online version for colours)

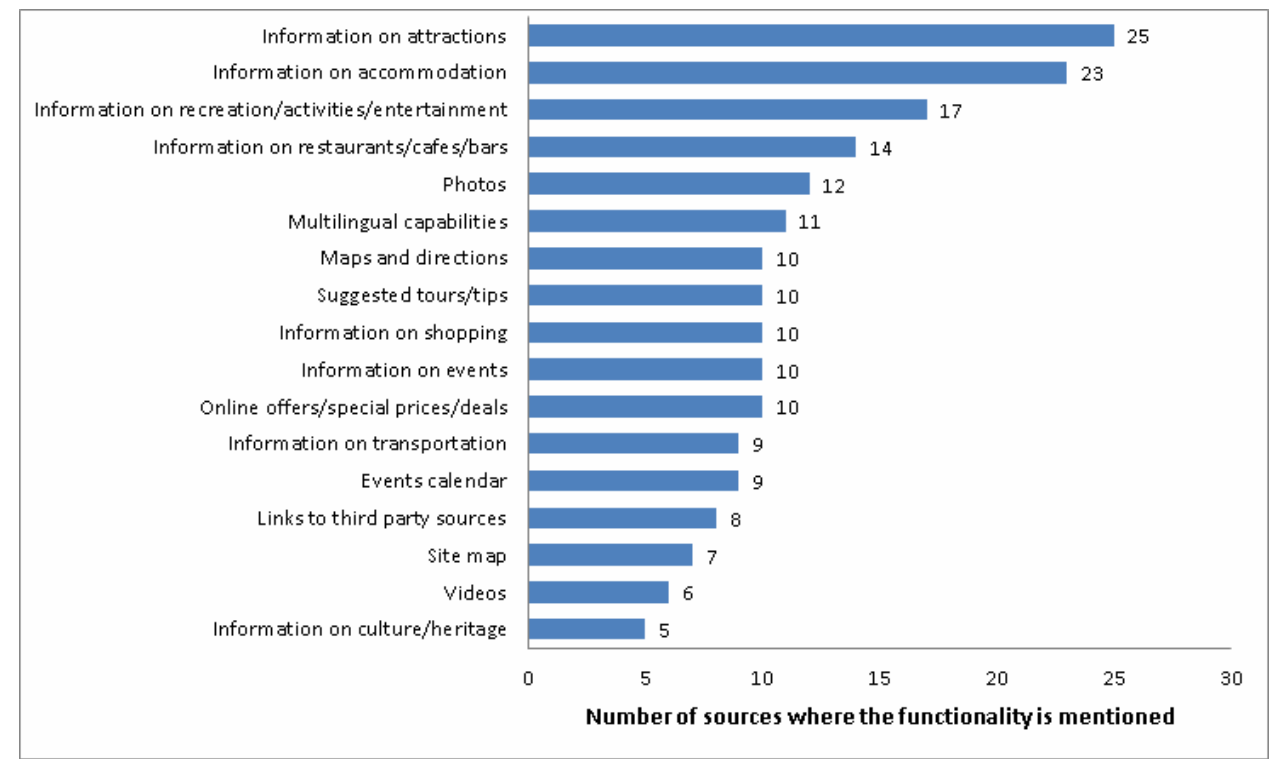

Note: Only functionalities mentioned at least in five sources are included in the figure. 
Figure 3 Most frequently referred functionalities in reviewed studies (communication/relationship dimension) (see online version for colours)

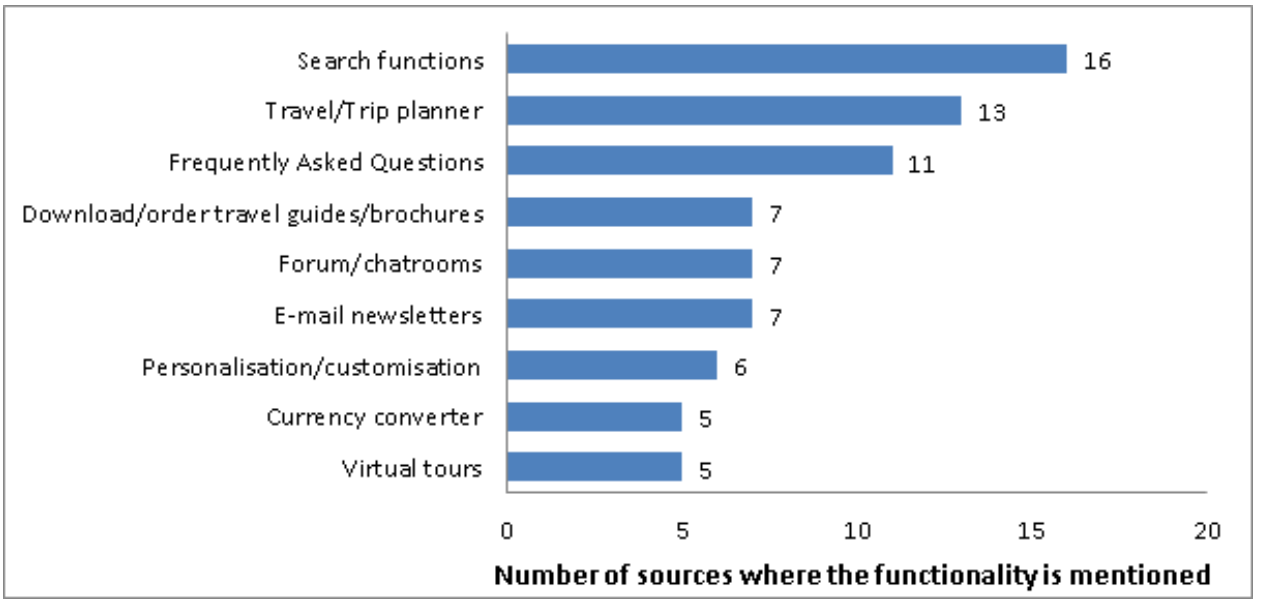

Note: Only functionalities mentioned at least in five sources are included in the figure.

Figure 4 Most frequently referred functionalities in reviewed studies (transaction dimension) (see online version for colours)

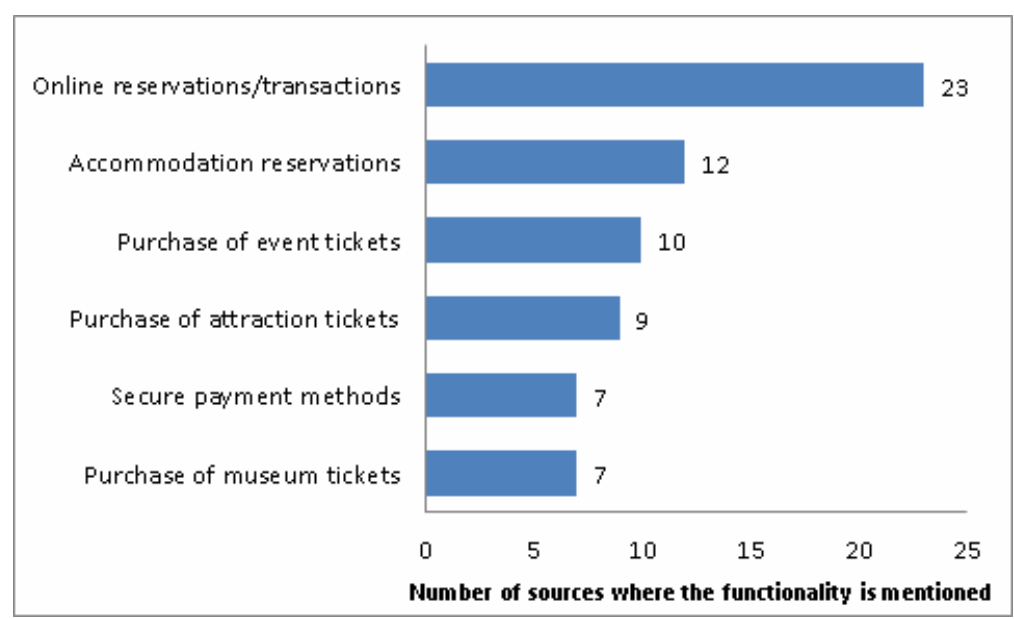

Note: Only functionalities mentioned at least in five sources are included in the figure.

\subsection{Frequency of references to website functionalities per types of tourism destination components}

As far as the informational dimension is concerned, the visualisation of information on 'CGR' was identified in 29 sources and the 'accommodation information' in 26 out of the total 48 (Figure 5). Therefore, these two components are the most frequently mentioned ones in this scope. Although two subcomponents of the 'attractions' category - 'events and entertainment' $(n=23)$ and 'unspecified attractions' $(n=25)$ - were often mentioned 
in the analysed sources, functionalities related to 'natural attractions' received the least amount of references $(n=4)$.

Figure 5 Number of references to types of informational functionalities (see online version for colours)

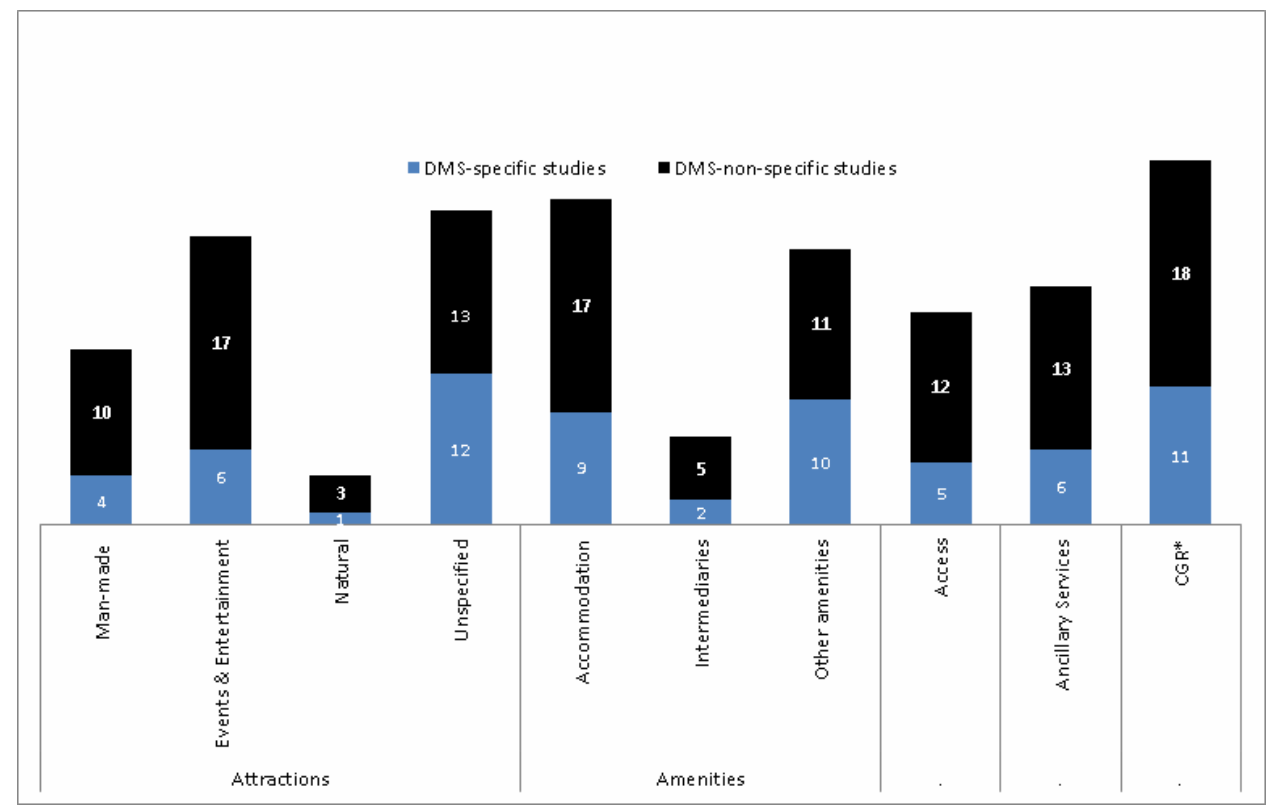

The communication/relationship functionalities found in the literature are more frequently associated to 'CGR' $(n=29)$, to 'ancillary services' $(n=20)$ and 'access' $(\mathrm{n}=13)$ (Figure 6). Few references are found on communication/relationship functionalities related to subcomponents of 'attractions' and of 'amenities'. Perhaps 'ancillary services' is the most widely identified component within the communication/ relationship dimension across the literature because, as already referred, these services are usually provided by DMOs and, in the last decades, DMOs' major role has shifted from information provision to customer relationship management, in which the development of communication tools fostering the direct relationship between destinations and visitors is extremely important. In the future, this tendency is likely to increase, as the growing relevance and adoption of social media tools by DMOs' web applications further empowers the relevance of destinations' web communication/ relationship with visitors (Mich and Kiyavitskaya, 2011).

Unlike the previous dimension, transaction seems to be more balanced regarding the number of references to each of the different destination components (Figure 7). The exception is the 'CGR', which is considerably more frequently referred $(\mathrm{n}=28)$ than all other nine categories. Transaction of 'accommodation' $(n=12)$ and transaction of 'events and entertainment' $(n=10)$ were, respectively, the second and third most often mentioned. As expected, by their inherently non-commercial nature, transaction of 'ancillary services' and transaction of 'natural attractions', received no references. 
Figure 6 Number of references to types of communication/relationship functionalities (see online version for colours)

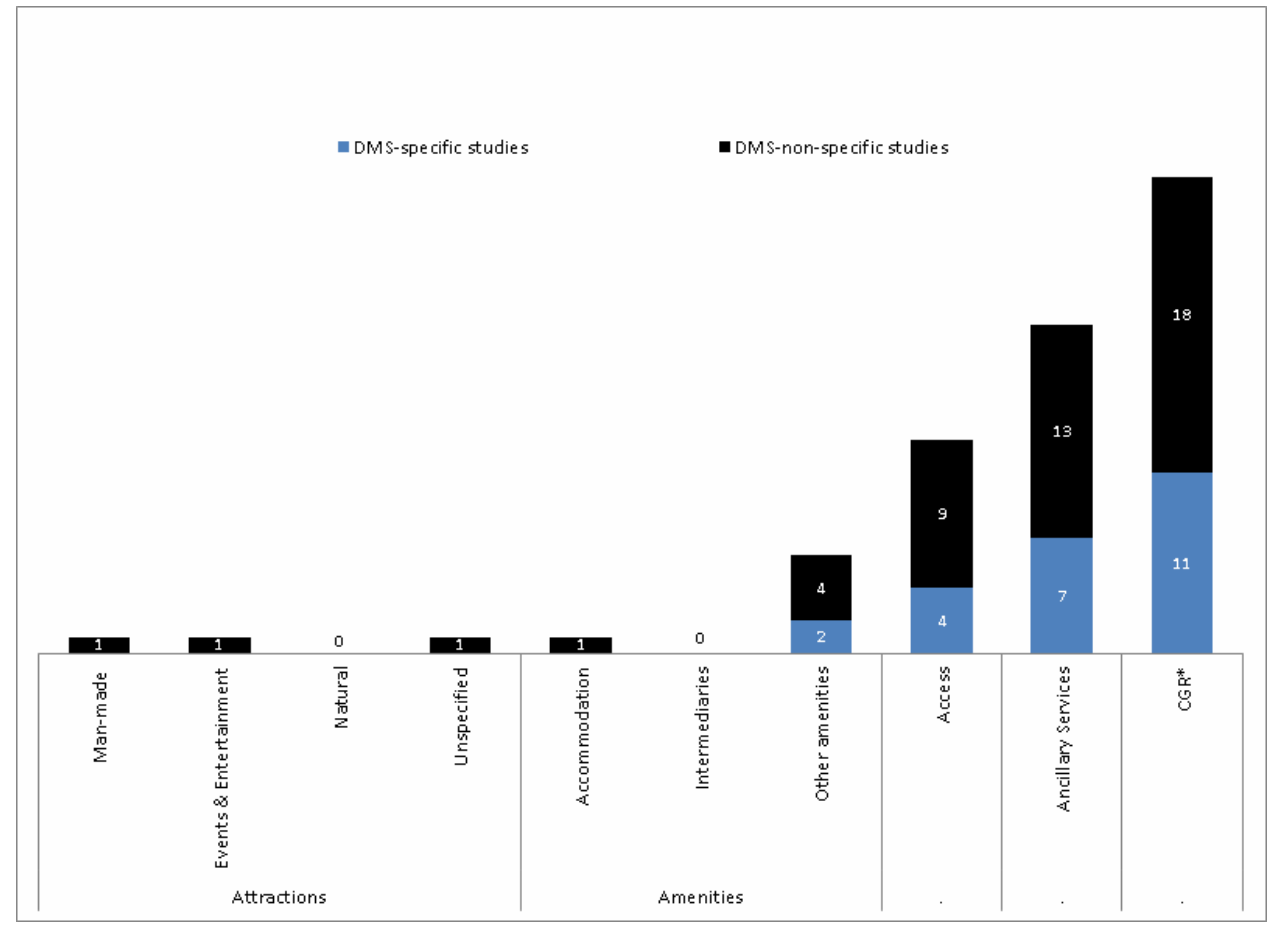

Figure 7 Number of references to types of transactional functionalities (see online version for colours)

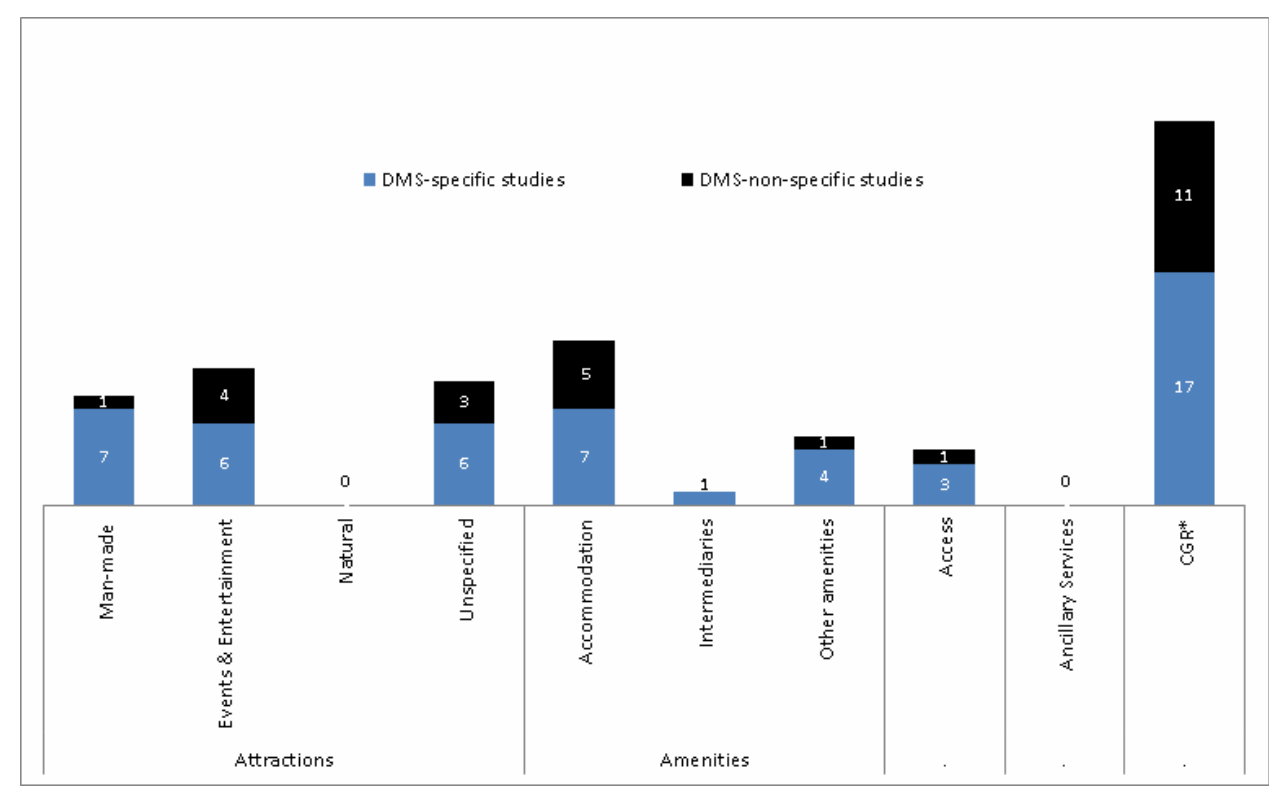




\subsection{Comparative analysis between functionalities identified in DMS-specific and DMS-non-specific literary sources}

As referred in the methodology section, from the total of 48 reviewed studies, 22 focused specifically on DMS while the remaining 26 dealt with unspecified DMO websites. As also indicated earlier, this study's major goal is comparing DMS-specific and DMS-non-specific sources in terms of references done to web functionalities. For each type of functionality identified in Figures 5 to 7 , a comparison is done between the percentage of DMS-specific studies and the percentage of DMS-non-specific studies that mention that type of functionality. Ultimately, this analysis would allow researchers to assess which of the two types of literature sources - DMS-specific or DMS-non-specific - gives more emphasis to each type of functionality.

Table 2 References in the DMS-specific and DMS-non-specific studies to functionalities, by dimension

\begin{tabular}{|c|c|c|c|c|c|c|c|}
\hline \multicolumn{2}{|c|}{ Component types } & \multicolumn{2}{|c|}{$\begin{array}{l}\text { DMS-specific } \\
\quad(n=22)\end{array}$} & \multicolumn{2}{|c|}{$\begin{array}{l}\text { DMS-non-specific } \\
\quad(n=26)\end{array}$} & \multirow[t]{2}{*}{$X^{2}$} & \multirow[t]{2}{*}{$p$-value } \\
\hline Information & Attractions & \begin{tabular}{c|}
$n$ \\
14
\end{tabular} & $\frac{\%}{64 \%}$ & $\begin{array}{c}n \\
21\end{array}$ & $\begin{array}{c}\% \\
81 \%\end{array}$ & & \\
\hline & Amenities & 14 & $64 \%$ & 20 & $77 \%$ & & \\
\hline & Access & 5 & $23 \%$ & 12 & $46 \%$ & & \\
\hline & Ancillary services & 6 & $27 \%$ & 13 & $50 \%$ & & \\
\hline & CGR & 11 & $50 \%$ & 18 & $69 \%$ & & \\
\hline \multicolumn{2}{|c|}{$\begin{array}{l}\text { Total references to the } \\
\text { information dimension }\end{array}$} & 19 & $86 \%$ & 24 & $92 \%$ & a) & \\
\hline \multirow{5}{*}{$\begin{array}{l}\text { Commun./ } \\
\text { relationship }\end{array}$} & Attractions & 1 & $5 \%$ & 1 & $4 \%$ & & \\
\hline & Amenities & 1 & $5 \%$ & 3 & $12 \%$ & & \\
\hline & Access & 4 & $18 \%$ & 9 & $35 \%$ & & \\
\hline & Ancillary services & 7 & $31 \%$ & 13 & $50 \%$ & & \\
\hline & CGR & 11 & $50 \%$ & 18 & $69 \%$ & & \\
\hline \multicolumn{2}{|c|}{$\begin{array}{l}\text { Total references to the communication } \\
\text { and relationship dimension }\end{array}$} & 17 & $77 \%$ & 20 & $77 \%$ & 0.001 & 0.977 \\
\hline \multirow[t]{5}{*}{ Transaction } & Attractions & 7 & $27 \%$ & 5 & $19 \%$ & & \\
\hline & Amenities & 8 & $36 \%$ & 5 & $19 \%$ & & \\
\hline & Access & 3 & $14 \%$ & 1 & $4 \%$ & & \\
\hline & Ancillary services & 0 & $0 \%$ & 0 & $0 \%$ & & \\
\hline & CGR & 17 & $77 \%$ & 11 & $42 \%$ & & \\
\hline \multicolumn{2}{|c|}{$\begin{array}{l}\text { Total references to the } \\
\text { transaction dimension }\end{array}$} & 21 & $95 \%$ & 16 & $62 \%$ & 7.760 & 0.005 \\
\hline
\end{tabular}

Note: a) Not valid

As presented in Table 2, chi-square tests revealed statistical significant differences between DMS-specific and non-specific studies only in the transactional dimension $\left(\mathrm{X}^{2}=7.760 ; \mathrm{p}\right.$-value $\left.=0.005\right)$. Interestingly, this dimension accounts for the highest percentage of references (95\%) within DMS-specific studies and the lowest proportion 
(62\%) amongst DMS-non-specific researches. Although these differences are not significant when comparing the results for the first four destination components individually, they are quite considerable when confronting the frequency of DMS-specific studies referring 'CGR' transactions (77\%) with that of DMS-non-specific researches $(42 \%)$.

While the information dimension was referred in $92 \%$ of DMS-non-specific studies, it was present in $86 \%$ of those specifically encompassing DMS. Noteworthy is also the fact that, within the information dimension, functionalities related to the 'attractions' component are the most widely identified in both DMS-specific and DMS-non-specific studies, respectively in $64 \%$ and $81 \%$. Contrastingly, functionalities related to 'access' are the least mentioned component in both types of studies. Some discrepancy is noticed between DMS-specific and DMS-non-specific researches in each of the destination components taken into consideration. Thus, while, for instance, 'ancillary services' were only referred in $27 \%$ of DMS-specific studies, they are pointed out by $50 \%$ of DMSnon-specific ones.

The results concerning the communication/relationship dimension are more similar in the two types of analysed studies. Overall, references to functionalities within this dimension can be identified in $77 \%$ of both - specific and DMS-non-specific sources. Additionally, considerable similarities are detected on individual components. Thus, for example, references to 'attractions' are found in 5\% of the DMS-specific studies and in $4 \%$ of DMS-non-specific analysed researches.

Figure 8 Differences between DMS-specific and DMS-non-specific platforms according to their functionalities' dimensions (see online version for colours)

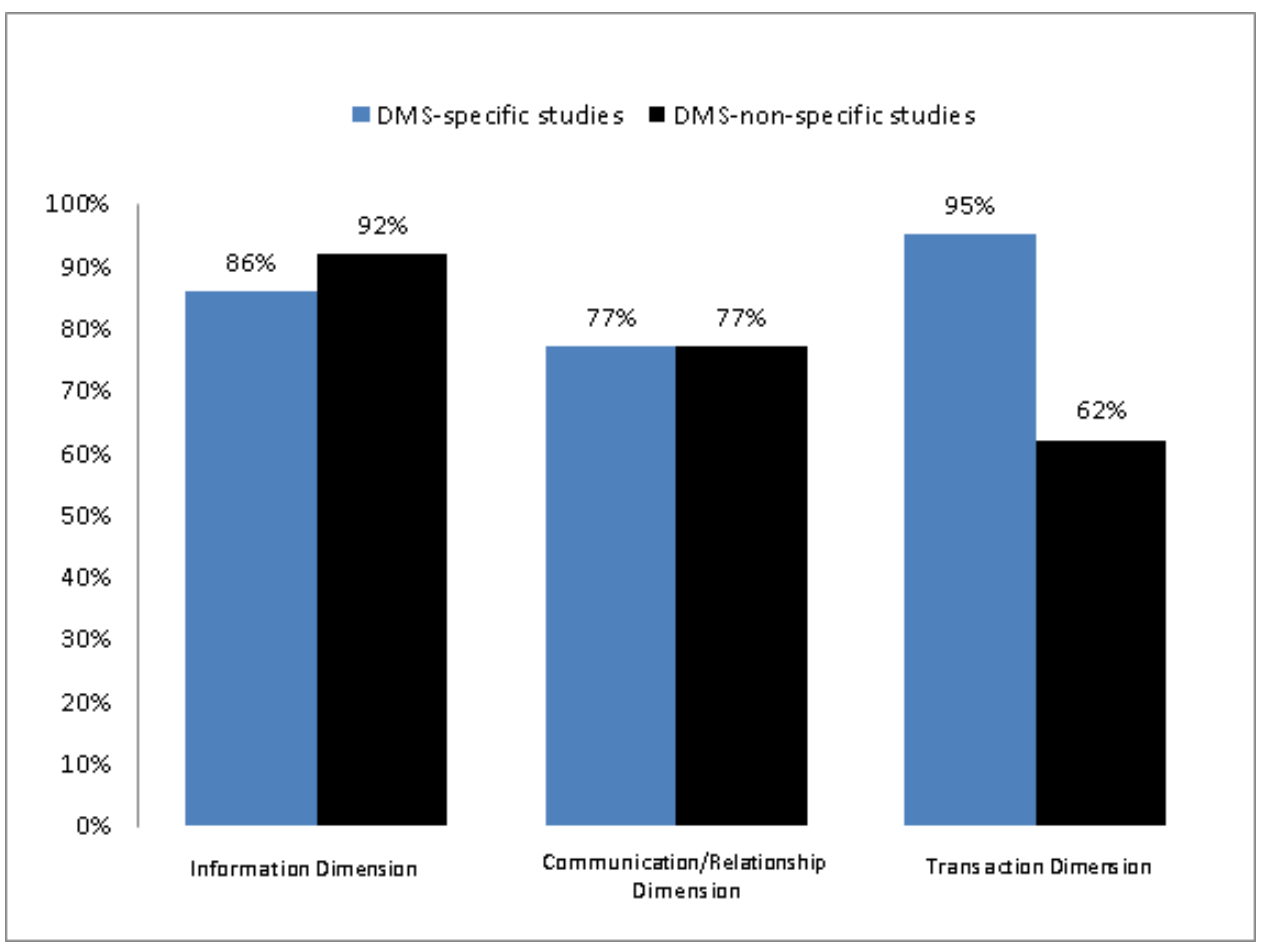


Figure 8 highlights the main differences between 'DMS' and 'DMO platforms not considered DMS'. It reveals that the distinctive characteristics of DMS rely on the functionalities included in the transaction dimension. The transaction functionalities are more predominant in 'DMS', while the information functionalities are more predominant in 'DMO platforms not considered DMS'.

\section{Conclusions}

The concepts of DMS proposed across the years point to a higher complexity of DMSs in relation to more traditional destination websites. However, the scarcity of studies on DMSs and other DMO websites/web-applications providing a systematic identification of functionalities, make it difficult to grasp the actual differences between these two types of tourism destinations' web platforms.

According to the literature, the main distinction between DMS and traditional DMO websites lies in the functionalities made available to the DMOs staff, for internally assisting and coordinating their operations, and those aimed at destination-based tourism businesses. In fact, as previously discussed, although DMSs are likely to encompass these functionalities, traditional DMO websites are almost entirely focused on the tourist demand and, consequently, in promoting destinations. Although the literature highlights the differences above referred, regarding functionalities targeted to potential visitors of tourism destinations, the distinction between DMSs and traditional DMO platforms is far from being clear. The present study contributes to clarify the frontiers of DMSs considering functionalities targeted to potential visitors.

The comparison between DMS-specific studies and DMS-non-specific studies analysed suggests that the major difference relies in the transactional dimension, particularly on transaction functionalities related to complementary general requirements (not associated to specific components of tourism destinations), that are more likely to be found in DMSs. As far as the information and communication/relationship dimensions are concerned, differences are not so clear. The results also suggest that the diverse information functionalities tend to be present in almost all DMSs and traditional DMO applications, while the majority of communication/relationship functionalities analysed tend still to be scarce in these two kinds of platforms. This last situation can be explained by the fact that much of this dimension's functionalities are still in their infancy, at least compared to information and transaction dimensions.

The present research also provides some guidelines to the development of DMSs. It is important that, alongside the investment in the informational dimension, DMOs also pay attention to the transactional and communicational/relationship dimensions of DMS, in order to increase the value of these systems to visitors. If DMOs want to take full advantage of their ISs and networks, they should evolve from the mere information and transaction dimensions towards underpinning a closer, more interactive and dynamic connection with their visitors through a broader and systematic use of tools empowering the relationship dimension.

Special attention should be given to include, in DMSs, the functionalities more frequently mentioned in the literature analysed, such as information on attractions, information on accommodation, information on recreational activities, search functions, travel/trip planner, frequently asked questions service, online reservations/transactions particularly reservations of accommodation and purchase of event and attraction tickets. 
The study also indicates a wide range of other functionalities that, besides not being frequently referred in the literature, may be included in DMSs to improve the value of these systems to potential visitors, such as: suggested tours, events calendar, download/order travel guides/brochures, virtual tours, and secure payment methods.

The analysis done in this study was strictly based on the literature. This may have been a limitation of this study. In order to overcome this limitation, future research should include content analysis of DMS platforms to identify the main functionalities already included in these kinds of systems. This study should be complemented by research designed to assess the relevance that visitors assign to the functionalities found in DMSs. Considering the constant evolution of technology, future research should be undertaken to evaluate the evolution of the 'DMSs' and 'DMO platforms not considered to be DMS' and identify future changes in the 'border' between them. We also suggest future works to develop an experimental prototype in order to validate the concept of DMS.

\section{References}

Alford, P. and Clarke, S. (2009) 'Information technology and tourism: a theoretical critique', Technovation, Vol. 29, No. 9, pp.580-587.

Baggio, R. (2008) 'The province of Rimini: communicating with the customer', in Egger, R. and Buhalis, D. (Eds.): eTourism - Case Studies, pp.213-223, Butterworth Heinemann, Oxford.

Bastida, U. and Huan, T.C. (2012) 'Performance evaluation of tourism websites' information quality of four global destination brands: Beijing, Hong Kong, Shanghai, and Taipei', Journal of Business Research [online] http://dx.doi.org/10.1016/j.jbusres.2012.10.008, in press.

Bédard, F. and Louillet, M. (2008) 'BonjourQuebec.com: a vision, a strategy, a brand', in Egger, R. and Buhalis, D. (Eds.): eTourism: Case Studies, pp.200-212, Butterworth Heinemann-Elsevier, Oxford.

Beldona, S. and Cai, L.A. (2006) 'An exploratory evaluation of rural tourism websites', Journal of Convention and Event Tourism, Vol. 8, No. 1, pp.69-80.

Benckendorff, P.J. and Black, N.L. (2000) 'Marketing on the internet: a case study of Australian regional tourism authorities', The Journal of Tourism Studies, Vol. 11, No. 1, pp.11-21.

Booch, G., Rumbaugh, J. and Jacobson, I. (1999) The Unified Modeling Language User Guide, Addison Wesley, Reading MA, USA.

Brown, G. (2004) 'Developing a destination management system to act as an enabler in sustaining a competitive advantage in the (net) marketplace', in Frew, A. (Ed.): Information and Communication Technologies in Tourism 2008, Springer, pp.326-336, Wien, New York.

Buhalis, D. (2003) eTourism: Information Technologies for Strategic Tourism Management, Pearson Higher Education, Harlow.

Buhalis, D. and Spada, A. (2000) 'DMS: criteria for success - an exploratory research', Information Technology and Tourism, Vol. 3, No. 1, pp.41-58.

Cano, V. and Prentice, R. (1998) 'Opportunities for endearment to place through electronic 'visiting': WWW homepages and the tourism promotion of Scotland', Tourism Management, Vol. 19, No. 1, pp.67-73.

Castells, M. (2001) A era da informação: Economia, sociedade e cultura - Volume I: A sociedade em rede, Fundação Calouste Gulbenkian, Lisboa.

Çetinkaya, A.Ş. (2009) 'Destination competitiveness through the use of information and communication technologies', European and Mediterranean Conference on Information Systems, Izmir, 13-14 July 2009. 
Chen, H-M. and Sheldon, P.J. (1997) 'Destination information systems: design issues and directions', Journal of Management Information Systems, Vol. 14, No. 2, pp.151-176.

Cho, M-H. and Sung, H.H. (2012) 'Travel destination websites: cross-cultural effects on perceived information value and performance evaluation', Journal of Travel and Tourism Marketing, Vol. 29, No. 3, pp.221-241.

Choi, S, Lehto, X.Y. and O'Leary, J.T. (2007a) 'What does the consumer want from a DMO website? A study of US and Canadian tourists' perspectives', International Journal of Tourism Research, Vol. 9, No. 2, pp.59-72.

Choi, S., Lehto, X.Y. and Morrison, A. (2007b) 'Destination image representation on the web: content analysis of Macau travel related websites', Tourism Management, Vol. 28, No. 1, pp.118-129.

Collins, C. and Buhalis, D. (2003) 'Destination management systems utilisation in England', in Frew, A.J., Hitz, M. and O'Connor, P. (Eds.): Information and Communication Technologies in Tourism 2003, pp.202-211, Springer, Wien, New York.

Cooper, C. (2006) 'Knowledge management and tourism', Annals of Tourism Research, Vol. 33, No. 1, pp.47-64.

Cooper, C., Fletcher, J. Wanhill, S., Gilbert, D. and Fyall, A. (2008) Tourism: Principles and Practice, 4th ed., Financial Times/Prentice Hall, Harlow.

Crouch, G.I. (2007) Modeling Destination Competitiveness: A Survey and Analysis of the Impact of Competitiveness Attributes, CRC for Sustainable Tourism Pty Ltd., Gold Coast (AUS).

Doolin, B., Burgess, B.L. and Cooper, J. (2002) 'Evaluating the use of the web for tourism marketing: a case study from New Zealand', Tourism Management, Vol. 23, No. 5, pp.557-561.

Douglas, A. and Mills, J.E. (2004) 'Staying afloat in the tropics: applying a structural equation model approach to evaluating National Tourism Organization websites in the Caribbean', Journal of Travel and Tourism Marketing, Vol. 17, Nos. 2/3, pp.269-293.

Dwyer, L., Edwards, D., Mistilis, N., Roman, C. and Scott, N. (2009) 'Destination and enterprise management for a tourism future', Tourism Management, Vol. 30, No. 1, pp.63-74.

Egger, R. and Buhalis, D. (2008) eTourism: Case Studies, Butterworth Heinemann-Elsevier, Oxford.

Estêvão, J.V., Carneiro, M.J. and Teixeira, L. (2011) 'The role of DMS in reshaping tourism destinations: an analysis of the Portuguese case', Information Technology and Tourism, Vol. 13, No. 3, pp.161-176.

Estêvão, J.V., Carneiro, M.J. and Teixeira, L. (2012) 'O papel dos Sistemas de Gestão de Destinos no desenvolvimento do turismo cultural: Análise da vertente transacional destes sistemas no que concerne a produtos turísticos culturais', Journal of Tourism and Development, Vols. 17/18, No. 3, pp.1611-1623.

Feng, R., Morrison, A.M. and Ismail, J.A. (2003) 'East versus West: a comparison of online destination marketing in China and the USA', Journal of Vacation Marketing, Vol. 10, No. 1, pp.43-56.

Gartrell, R.B. (1988) Destination Marketing for Convention and Visitor Bureaus, Kendall/Hunt Publishing Company, Iowa.

Giannopoulos, A.A. and Mavragani, E.P. (2011) 'Traveling through the web: a first step toward a comparative analysis of European national tourism websites', Journal of Hospitality Marketing and Management, Vol. 20, No. 7, pp.718-739.

Gretzel, U., Fesenmaier, D.R., Formica, S. and O'Leary, J.T. (2006) 'Searching for the future: challenges faced by destination marketing organizations', Journal of Travel Research, Vol. 45, No. 2, pp.116-126.

Guthrie, C. (2008) 'VisitBritain: satisfying the online market dynamics', in Egger, R. and Buhalis, D. (Eds.): eTourism: Case Studies, pp.181-189, Butterworth Heinemann-Elsevier, Oxford. 
Hall, C.M. (2000) Tourism Planning: Policies, Processes and Relationships, Pearson Education, Harlow.

Han, J. and Mills, J.E. (2006) 'Zero acquaintance benchmarking at travel destination websites: What is the first impression that National Tourism Organizations try to make?', International Journal of Tourism Research, Vol. 8, No. 6, pp.405-430.

Ho, S-C., Kauffman, R.J. and Liang, T-P. (2007) 'A growth theory perspective on B2C e-commerce growth in Europe: an exploratory study', Electronic Commerce Research and Applications, Vol. 6, No. 3, pp.237-259.

Internet World Stats (2013) Internet Usage Statistics: The Big Picture [online] http://www.internetworldstats.com/stats.htm (accessed January 2013).

Inversini, A. (2011) Cultural Destinations' Online Communication and Promotion: Discovering Official and Unofficial Online Sources Peculiarities of Cultural Destinations Promotion, LAP-Lambert Academic Publishing, Saarbrücken, Germany.

Inversini, A. and Cantoni, L. (2009) 'Cultural destination usability: the case of Visit Bath', in Hopken, W., Gretzel, U. and Law, R. (Eds.): Information and Communication Technologies in Tourism, pp.319-331, Springer, Wien, New York.

JupiterResearch (2011) Jupiter Research Report 2006-2011 [online] http://www.jupiterresearch.com (accessed July 2012).

Kao, Y.F., Louvieris, P., Powell-Perry, J. and Buhalis, D. (2005) 'E-satisfaction of NTO's website case study: Singapore tourism board's Taiwan website', in Frew, A.J. (Ed.): Information and Communication Technologies in Tourism 2005, pp.227-237, Springer, Wien, New York.

Kärcher, K. and Alford, P. (2008) 'Tiscover: destination management system pioneer', in Egger, R. and Buhalis, D. (Eds.): eTourism: Case Studies, pp.233-242, Butterworth Heinemann-Elsevier, Oxford.

Kotler, P., Bowen, J. and Makens, J. (2003) Marketing for Hospitality and Tourism, 3rd ed., Pearson Education, New Jersey.

Li, X. and Wang, Y. (2010) 'Evaluating the effectiveness of destination marketing organizations' websites: evidence from China', International Journal of Tourism Research, Vol. 12, No. 5, pp.536-549.

Loda, M.D., Teichmann, K. and Zins, A.H. (2009) 'Destination websites' persuasiveness', International Journal of Culture, Tourism and Hospitality Research, Vol. 3, No. 1, pp.70-80.

Luna-Nevarez, C. and Hyman, M.R. (2012) 'Common practices in destination website design', Journal of Destination Marketing and Management, Vol. 1, Nos. 1-2, pp.94-106.

Mich, L. and Kiyavistkaya, N. (2011) 'Mapping the web presences of tourism destinations: an analysis of the European countries', in Law, R., Fuchs, M. and Ricci, F. (Eds.): Information and Communication Technologies in Tourism 201, pp.379-390, Springer, Wien, New York.

Middleton, V. and Clarke, J. (2002) Marketing in Travel and Tourism, Butterworth Heinemann, Oxford.

Milheiro, E. (2006) A informação turística e as tecnologias da informação e da comunicação: o caso português, Instituto de Turismo de Portugal, Lisboa.

Miralbell, O., Martell, E. and Viu, M. (2008) 'Spain.info: towards stakeholder network', in Egger, R. and Buhalis, D. (Eds.): eTourism: Case Studies, pp.190-199, Butterworth Heinemann-Elsevier, Oxford.

Morrison, A.M., Taylor, J.S. and Douglas, A. (2004) 'Website evaluation in tourism and hospitality', Journal of Travel and Tourism, Vol. 17, Nos. 2/3, pp.233-251.

Ndou, V. and Petti, C. (2007) 'DMS business models design and destination configurations: choice and implementation issues', Information Technology and Tourism, Vol. 9, No. 1, pp.3-14.

O’Connor, P. and Rafferty, J. (1997) ‘Gulliver: distributing Irish tourism electronically', Electronic Markets, Vol. 7, No. 2, pp.40-46. 
O'Reilly, T. (2005) What is Web 2.0 - Design Patterns and Business Models for the Next Generation of Software [online] http://www.oreillynet.com/pub/a/oreilly/tim/news/2005/09/ 30/whatis-web-20.html (accessed February 2011).

Öörni, A. (2004) 'Consumer objectives and the amount of search in electronic travel and tourism markets', Journal of Travel and Tourism Marketing, Vol. 17, Nos. 2/3, pp.3-14.

Pechlaner, H. and Raich, M. (2002) 'The role of information technology in the information process for cultural products and services in tourism destinations', Information Technology and Tourism, Vol. 4, No. 2, pp.91-106.

Petti, C. and Solazzo, G. (2007) 'Architectural scenarios supporting e-business models for a DMS', in Sigala, M., Mich, L. and Murphy, J. (Eds.): Information and Communication Technologies in Tourism 2007, pp.195-206, Springer, Wien, New York.

Pollock, A. (1995) 'The impact of information technology on destination marketing', Travel and Tourism Analyst, No. 3, pp.66-83.

Qi, S., Law, R. and Buhalis, D. (2008) 'Usability of Chinese destination management organization websites', Journal of Travel and Tourism Marketing, Vol. 25, No. 2, pp.182-198.

Rita, P. (2000) 'Web marketing tourism destinations', European Conference on Information Systems.

Schröcksnadel, M. (2008) 'Feratel media technologies: providing DMS technology', in Egger, R. and Buhalis, D. (Eds.): eTourism: Case Studies, pp.243-251, Butterworth-Heinemann, Oxford.

So, S.A. and Morrison, A.M. (2004) 'Internet marketing in tourism in Asia: an evaluation of the performance of East Asian National Tourism Organization websites', Journal of Hospitality and Leisure Marketing, Vol. 11, No. 4, pp.93-118.

Stepchenkova, S., Tang, L., Jang, S., Kirilenko, A.P. and Morrison, A.M. (2010) 'Benchmarking CVB website performance: spatial and structural patterns', Tourism Management, Vol. 31, pp.611-620.

Sussmann, S. and Baker, M. (1996) 'Responding to the electronic marketplace: lessons from destination management systems', International Journal of Hospitality Management, Vol. 15, No. 2, pp.99-112.

Teichmann, K. and Zins, A.H. (2008) 'Information elements on DMO-websites: alternative approaches for measuring perceived utility', in O'Connor, P., Höpken, W. and Gretzel, U. (Eds.): Information and Communication Technologies in Tourism 2008, pp.209-219, Springer, Wien, New York.

The European e-Business Market Watch (2005) 'Case study: the online destination management system of Gulliver, Ireland', ICT and Electronic Business in the Tourism Industry. ICT Adoption and e-Business Activity in 2005, pp.45-52, European Commission, Brussels.

Wang, Y. (2008) 'Web-based destination marketing systems: assessing the critical factors for management and implementation', International Journal of Tourism Research, Vol. 10, No. 1, pp.55-70.

Wang, Y. and Fesenmaier, D.R. (2006) 'Identifying the success factors of web-based marketing strategy: an investigation of convention and visitors bureaus in the United States', Journal of Travel Research, Vol. 44, No. 3, pp.239-249.

Wang, Y. and Russo, S.M. (2007) 'Conceptualizing and evaluating the functions of destination marketing systems', Journal of Vacation Marketing, Vol. 13, No. 3, pp.187-203.

Wei, Z. and Jiu-wei, W. (2009) 'A study on the information integrated mechanism of tourist destination marketing system', Paper presented at the E-Business and Information System Security - EBISS.

Werthner, H. and Klein, S. (1999) Information Technology and Tourism - A Challenging Relationship, Springer, Wien, New York.

Wöber, K.W. (2003) 'Information supply in tourism management by marketing decision support systems', Tourism Management, Vol. 24, No. 3, pp.241-255. 
World Tourism Organization (2001) E-business for Tourism: Practical Guidelines for Tourism Destinations and Businesses, World Tourism Organization, Madrid.

World Tourism Organization (2004) World Tourism Organization Survey of Destination Management Organisations Report, World Tourism Organization, Madrid.

World Tourism Organization Business Council (1999) 'Introduction', Marketing Tourism Destinations Online: Strategies for the Information Age, Ch. 1, World Tourism Organization, Madrid.

Yoo, K.H. and Gretzel, U. (2010) 'Antecedents and impacts of trust in travel-related consumer-generated media', Information Technology and Tourism, Vol. 12, No. 2, pp.139-152.

Zhou, Q. and DeSantis, R. (2005) 'Usability issues in city tourism website design: a content analysis', International Professional Communication Conference, Institute of Electrical and Electronics Engineers (IEEE), Limerick, Ireland. 